\title{
ECONOMIC AND LEGAL ASPECTS OF THE FRANCHISE AGREEMENT IN POLAND
}

\author{
Petro Nemesh ${ }^{1}$, Vitalii Kadala ${ }^{2}$
}

\begin{abstract}
The purpose of the article is to study the economic and legal nature of the franchise agreement in Poland. Since franchising in this country has become the most common way of establishing a business, it is advisable to identify the key economic and legal features of the franchise agreement in which the parties specify their rights and obligations, the franchise price, the duration of the franchise relations, the procedure for performing calculations, etc. The subject of the study is a franchise agreement in Poland. Research methodology. The research is based on the use of general scientific and special-scientific methods and techniques of scientific knowledge. The dialectical method allowed us to investigate the definition of a franchise agreement in Poland and its key terms. The comparative legal method was used to compare doctrinal approaches to this issue. The statistical method was used to establish data that reflects the effectiveness of franchising activities. The method of system analysis helped to find out in which areas of economic activity franchising is most demanded. Interpretation of the content of Polish legal acts governing issues related to the conclusion of a franchise agreement in this country was realized with the help of the normative-dogmatic method. The system-structural method was used to study the franchise agreement in Poland as a single entity (system) with the coordinated functioning of all its elements. The methods of grouping and classifying formed the basis for separating the list of conditions, which are necessary for concluding a franchise agreement in Poland, as well as provisions that should be included in the content of this agreement. Methods of analysis and synthesis helped to study some parts of this agreement to formulate further conclusions. Practical application. The positive experience of Poland in regulating issues related to the conclusion of a franchise agreement can be used for making appropriate changes to the Ukrainian legislation. Although there is no special legislation in Poland, which regulates the issues connected with this kind of contract, the adoption of a number of progressive economic measures, as well as complement existing regulations with the provisions on franchising, allowed Poland to become one of the most attractive countries for foreign entrepreneurs. Correlation/originality. This scientific work is the first research in Ukraine devoted not only to general issues of regulation of franchising activity in Europe but specifically to the franchise agreement in a separate country (in Poland) and its legal and economic peculiarities.
\end{abstract}

Key words: franchising, franchise contract, franchisor, franchisee, disclose, contract terms, antitrust agreements, safe harbour.

JEL Classification: K12, F55

\section{Introduction}

Franchising is a form of entrepreneurial activity that is constantly growing and has become increasingly widespread and effective in recent years. Big companies are increasingly using the franchising system to expand their network, which has proven its suitability worldwide. Franchising is applied in almost all areas of business - from fast food restaurants to gas stations.

Franchising is a widespread way of opening a business in Poland. Over the past 15 years, this country has achieved significant economic success by modernizing the economy and stabilizing it. Poland is one of the fastest developing countries in Europe. This fact is

Corresponding author:

${ }^{1}$ Uzhhorod National University, Ukraine.

${ }^{2}$ Donetsk Law Institute of the Ministry of Internal Affairs of Ukraine, Ukraine. confirmed by various market indicators, such as gross domestic product (GDP), consumer price index, labour market structure, competitive wages and dynamic foreign trade turnover. With GDP growth of $4.6 \%$ in 2017, Poland remains among the leaders of European countries. In the same year, the Eurozone has been growing by $2.5 \%$ and the whole EU - by $2.5 \%$ (Polish Franchise Organization).

Costs of conducting business in Poland are significantly lower than in Western Europe. Moderate labour value is also an attractive factor for foreign investors. Although the economy of this state is not yet in line with the economies of other European countries, 
EU membership has played an important role in its strengthening. In recent years, more and more foreign entrepreneurs (including from neighbouring Ukraine and CIS countries) invest money into a stable economy of a rapidly expanding Polish state.

Foreign franchises are developing successfully in the Polish market. According to expert appraisement, more than 10,000 franchise companies are launched annually in Poland. Polish businessmen perceive franchising as a safe business concept. The number of "multifunctional franchisees" (entrepreneurs who own more than one branch) is growing, which is evidence of a high level of confidence in the franchising system.

Most entrepreneurs prefer to develop their business in already proven and demanded industries. In this regard, a large part of the franchises Polish market is occupied by grocery stores. High growth rates are also observed in the service sector. Especially popular are franchises related to providing professional advice and legal support.

National franchises occupy more than $85 \%$ of the market in Poland. Polish franchises are also successful in other countries, for example, in Ukraine, Russia, the Czech Republic, as well as in other countries of Central and Eastern Europe.

The study of franchising as a type of international business was undertaken by N. V. Bezrukova, L. V. Voroniak, T. M. Hryhorenko, N. M. Hrushchynska, O. M. Kolodiziev, O. Ye. Kuzmin, A. M. Mahomedova, V. Ye. Sakharov, V. S. Tatarinov, T. M. Tsyhankova, A. V. Tsyrat, I. M. Shkola and others. However, this would be the first study in Ukraine devoted to franchising in Poland, and in particular, the economic and legal characteristics of the franchise agreement in this country.

In connection with the course of Ukraine on European integration, it is reasonable to study the positive experience of leading European countries for its further application to the legislation of our state. Therefore, the purpose of this article is to study economic and legal characteristics of the franchise agreement in Poland - the state with a fully-developed franchising market which is constantly growing, and that has been achieved only in the last 15 years.

\section{Statement of the baseline}

The Polish franchising market is mature but is steadily growing. Local entrepreneurs are aware of many potential alternatives that allow them to decide on future prospects for franchising. According to the private franchising consulting company PROFIT System, in 2017 the Polish franchise sector covered 1,220 independent franchise networks and more than 71,400 franchise stores and service sectors. Franchising is one of the fastest growing options for small private firms. According to the data, the average franchise "employs" 5-6 people, and this sector as a whole provides 460000 jobs in Poland.

The average investment in a franchise in 2017 amounted to USD 40,000. Most of the franchise networks - 85\% - originated in Poland. The largest franchising sector with 204 brands is gastronomy. The leading brands are KFC, Starbucks, Pizza Hut, Dunkin' Donuts, Subway, and McDonald's. It is followed by retailing with 156 retail brands and 36,000 licensed locations (Poland Country Commercial Guide).

The largest Polish players on the franchising market are wholesale company Eurocash Group, convenience stores chain Zabka, spirits stores chain Al Capone, boutiques of women's underwear Esotiq, Getin Bank and BPH Bank, the largest network of payment agencies Monetia, retail store LPP Group, retail cosmetics sales company Inglot, courier service $\mathrm{Pl}$, street food network Kołacz, the first network of training centres Lauren Peso Polska SA, petrol stations network Lotos, and restaurant chain Sphinx (Maciej Gawroński, 2015).

One of the fastest growing trends is online sales, especially in the food and retail sectors. Online ordering of products is becoming popular in Poland nowadays. For example, Uber Eats is available in Poland as well. Local catering companies such as Blue Apron also appear.

Companies, which are members of Polish Franchise Organization (PFO) use the European Code of Ethics for Franchising (hereinafter - the Code of Ethics), adopted by the European Federation of Franchising, which member Poland is. Membership in the PFO is not mandatory, but it is recommended. The advantages of membership in the PFO are, among other things, quick and more favourable opportunities for cooperation with reliable franchisees. Members of the PFO also enjoy a better reputation among franchisees since they receive a certificate of trust when joining the organization, which is a confirmation of the quality of the networks and their compliance with the requirements of the Code of Ethics.

There are no clearly defined rules and regulations, which regulate franchising activities in Polish law. This also applies to franchise agreements, which are mostly concluded in accordance with the provisions of the contract law. The rules governing franchising activities are contained, among others, in: the Civil Code; the Consumer Protection Law; The competition Law; General data protection Regulation; The Labour Code; unfair trading practices.

In addition, Polish courts establish certain legal features for regulating the relationship between the franchisor and the franchisee in their decisions. Thus, the Supreme Court of Poland in the Case № I CSK 348/06 as of 07 July 2007, has decided (in accordance with previous decisions of the civil court, administrative court and competition court) that the essence of the franchising method of cooperation is to contractual obligation of 
the franchisor to allow the franchisee to use the mark, emblem, symbols, patents of the company, as well as technical and organizational know-how (concept), while the franchisee obliges to perform the specified entrepreneurial activity using the right of obtaining new customers (to open new outlets), which was provided to him by the franchisor. The Supreme Court also found that one of the main goals of franchising is to gather information about the market where the franchisee will develop franchising business and optimize sales processes. In addition, the decision stated that during the term of the franchise agreement, the franchisee operates and concludes contracts sui juris with new partners and also acquires new retail outlets. Finally, the Supreme Court confirmed that the franchise agreement is a longterm and reciprocal agreement, according to which the franchisor's mutual obligation cannot be assessed in terms of equivalence (Franchise, 2019).

There is no legal definition of the franchise agreement in Poland, that is, it belongs to unnamed contracts. It is subject to the general principles for the conclusion of contracts, which are prescribed in the Civil Code of Poland (hereinafter - the Civil Code) (Ustava $\mathrm{z}$ dnia 23 kwietnia 1964). For example, section 7 of this normative legal act consolidates the principle of integrity, which is presumed. The principle of freedom of contract is prescribed in section 351-1. According to this principle, the contracting parties may establish legal relations at their own discretion, if the content or purpose of the agreement does not contradict the rules of the statutory law or the basic principles of community life.

The principle of community life (zasady współżycia spolecznego) is reflected in section 5 of the Civil Code. On the basis of this principle, any legal act may be declared void if it does not meet the minimum standards of generally accepted notions of honesty and correctness in relations with individuals and legal entities (that is, if it is substantially unjust).

Concerning the relations between entrepreneurs, the principle of community life should be understood as the principle of "fair treatment" (zasady uczciwego obrotu), reliability, decency, trust and loyalty to the contractor. Each entrepreneur should refrain from any action, which would be a sign of a lack of respect to their contractors' interests and/or would cause injury in their interests (Franchise, 2019).

The franchise agreement contains the features of various types of contracts, such as: purchase, sale, supply, licensing, lease, commission, agency, and labour. In the scientific literature, when conducting the characteristics of the subject of the franchise contract, the specified contracts are often mentioned. Such comparisons with other agreements that are similar in structural or functional terms are due to the lack of special regulation in Polish law.

The franchise agreement must be concluded in accordance with the norms of the national legislation, the laws of the European Community and the requirements of the Code of Ethics. It is important that it reflects the interests of all members of the franchise network. It concerns both the protection of the franchisor's industrial and intellectual property and the preservation of the image and reputation of the franchise network (Anna Stronczek).

M. Gawroński defines the franchise agreement as an agreement between independent entities, under which the franchisee is directly or indirectly obliged to resell goods that have been bought from the franchisor and to use intellectual property rights and know-how that have been licensed from the franchisor. However, as the author notes it by herself since this definition is too broad, it is better to apply a narrower definition given by the European Federation of Franchising (Maciej Gawroński, 2015).

In practice, the definition given in paragraph 1 of the Code of Ethics (European Code of Ethics for franchising) adopted by the European Federation of Franchising is used. According to this definition, franchising is a system of marketing goods and/or services and/or technology, which is based upon a close and ongoing collaboration between legally and financially separate and independent undertakings, the Franchisor and its individual Franchisees, whereby the Franchisor grants its individual Franchisee the right, and imposes the obligation, to conduct a business in accordance with the Franchisor's concept. The right entitles and compels the individual Franchisee, in exchange for a direct or indirect financial consideration, to use the Franchisor's trade name, and/or trade mark and/or service mark, know-how, business and technical methods, procedural system, and other industrial and/ or intellectual property rights, supported by continuing provision of commercial and technical assistance, within the framework and for the term of a written franchise agreement, concluded between parties for this purpose.

The law does not impose any restrictions on the franchisor's organizational form, but the most widespread organizational form in Poland is a limited liability company. Other popular forms of entrepreneurial activity are: general partnership, joint-stock company, the limited partnership and the limited joint-stock partnership. Over the past few years, there has been a significant increase in the number of limited liability companies. This is due to the convenient system of taxation since only the income of the members of the company is subject to taxation, and not the income of the company itself.

Many individuals in Poland choose an individual entrepreneurial activity. Their part accounts for $73 \%$ of the total number of entrepreneurs in the private sector. Foreign investors open branch offices in Poland, through the intermediary of which they conduct their business in Poland in the same way as they do in their home countries.

Since more than $85 \%$ of franchise networks in Poland are local, the most popular is that type of franchising which does not require a significant initial investment. 
The Civil Code does not stipulate for the binding obligation to disclose information before concluding a franchise agreement, as it is provided in most other European countries. In practice, many franchisors do not disclose information or disclose it in very limited terms. It is the potential franchisee who can demand, request, and investigate certain information from relevant sources and evaluate it in terms of equivalence.

However, it is allowed to provide directly in the provisions of the franchise agreement that nonperformance of certain actions (for example, disclosure obligations) gives a franchisee the right to cancel the contract and/or demand damages. Otherwise, the general rules of the civil law for compensation are applied, and a franchisee will be obliged to prove the existence of damages in order to claim compensation. Also, according to the general principles of contractual law, one party has the right to rescind a reciprocal contract (for example, a franchise agreement) if the other party fails to fulfil its obligations (section 492 of the Civil Code), or demand that the obligation be performed and that any damage resulting from the default be remedied (section 491, paragraph 1 of the Civil Code).

Since there is no statutory disclosure obligation in Poland, the standard franchise agreement does not usually include any provision for data disclosure. However, the contract, as a rule, contains the provision about the refusal to provide such data, which is an effective means to protect franchisee's rights. So, in the case of non-disclosure of important information or providing false data, which is necessary for the effective business process, the franchisee will have a legitimate reason to rescind the franchising agreement. The franchisee may rescind the contract, even if the information hidden by the franchisor is not substantial. The franchise agreement can be terminated within a year from the detection of the false nature of the information provided.

There is a prescription for the protection of confidential information that may be provided during negotiations in section 72-1 of the Civil Code. So, if, during negotiations, a party makes information available with a stipulation of confidentiality, the other party cannot disclose or submit the same to other persons or use the same for its own purposes unless the parties agree otherwise. In case of non-performance or improper performance of this obligation, the entitled party may demand that the other party remedy any damage or hand over any benefits, which it has obtained.

The civil law of Poland does not provide for essential terms of the franchise agreement. According to section 72 the Civil Code, if the parties hold negotiations in order to execute a specific contract, the contract is executed when the parties reach an agreement on all the provisions, which were the subject of the negotiations, that is, the parties determine the terms of the future contract at their own discretion. Nevertheless, paragraph 5.4 of the Code of Ethics contains a list of conditions that is advisable to include in the content of a franchise agreement.

The validity of the franchising agreement is not legally binding, as the parties, as it was already noted, are free to agree on the terms of the contract. The maximum permitted duration of the agreement will depend on whether it contains any provisions restricting competition (for example, the provisions on territorial exclusivity). Moreover, the maximum allowed validity of such clauses (if any) will depend on whether the block exemption automatically applies in accordance with the Block Exemption Regulation (BER), adopted in accordance with section 101, paragraph 3 of the Treaty on the Functioning of the European Union (Commission Regulation). Thus, if the franchise agreement contains restrictive provisions, it may be exempted from the prohibition of the conclusion of antitrust agreements if the total market share of competitors in the relevant market does not exceed 5 per cent, or the market share of each non-competing entity in the relevant market does not exceed 10 per cent. This provision is called the de minimis principle, but it does not generally apply to franchise agreements, as they usually include provisions aimed at market sharing between the parties. If the de minimis principle cannot be applied, the franchise agreement may be exempted from the prohibition in accordance with the BER, which apply only to contracts that do not contain certain types of severe restrictions of competition, and the market share of the franchisor and franchisee in the relevant market does not exceed 30 percent (clause 8 of the BER).

If market shares of the parties to the agreement in the relevant market exceed, or if the franchise agreement contains hard-core restrictions, such an agreement falls under the BER regulation. However, the parties are entitled to apply for an individual exemption if they prove that their franchising network is more profitable than the effect of anticompetitive rules in the relevant market. In this case, the burden of proof lies on the entities (Maciej Gawroński, 2015).

If the agreement contains a clause requiring the franchisee to acquire at least $80 \%$ of the corresponding product from the franchisor or its assigned supplier or other terms restricting competition, then the maximum term of such conditions is established within the limits of "safe harbour" of the relevant clause on block exemptions applied. The clause on the automatic application of a "safe harbour" for non-competition clauses (e.g. exclusive supply provisions) may be provided by the parties in the content of the franchise agreement if they hold a market share of no more than $30 \%$ in the relevant market. The term of such an agreement is five years or is equal to the duration of the franchisee's rent of premises, which is the property of the franchisor. 
In order to protect the franchisor's know-how, the parties may put in the contract the clause on noncompetition, the validity of which cannot be more than one year after the termination of the agreement. During this period, the franchisee obliges not to conduct any transactions with goods which are similar to that provided by the franchisee in the premises where the franchisee worked during the term of the contract. If the franchisor transfers to the franchisee know-how, which is not a public domain, then the parties may stipulate for the clause on non-competition for a longer period (Franchise, 2019).

A franchise agreement is a long-term contract, which is concluded for a limited period (from five to twenty years). The civil law provides for two options to terminate the agreement before its expiration: termination upon notice and rescission. Thus, it may be stipulated that one or both parties will have the right to rescind the contract during a specified period. This right is exercised by a declaration being made to the other party (section 395, paragraph 1 of the Civil Code). If the right to rescind is exercised, a contract is deemed not to have been executed. Whatever the parties have already provided is returned unchanged unless the change was necessary as a part of ordinary management. The other party is entitled to appropriate remuneration for the services provided and for using a thing (section 395, paragraph 2 of the Civil Code).

Termination upon notice is applied for termination of contracts concluded for an indefinite period. A contract can be terminated only upon notice ex nunc, which means that the notice is valid only for the future and not the past. As a rule, termination upon notice applies only to the relation expended in time. Generally, there is a notice period after which the agreement terminates (it might be a contractual, statutory or a customary term period). If such period is not stipulated, the contract is considered to be terminated immediately on receipt of the notice (Maciej Gawroński, 2015).

Rescission is the means to protect parties' interests from the breach of contract terms. Thus, if one of the parties defaults in the performance of an obligation under a reciprocal contract, the other party may set an additional period for its performance with the sanction that if the specified period passes to no effect, it will be entitled to rescind the contract.

If the right to rescind a reciprocal contract is stipulated for non-performance of an obligation within a strictly specified period, the entitled party may, if the other party defaults, rescind the contract without setting an additional period. The same applies where the performance of an obligation by one of the parties after the period set would be meaningless to the other party due to the nature of the obligation or due to the purpose of the contract intended by it and known to the defaulting party.
That's why it is recommended to include the provisions on the conditions of franchise agreement termination to avoid the risk of a dispute between the parties.

\section{Conclusion}

Based on the foregoing, we can conclude that there has been a rapid development of franchising activities in Poland in recent years and its popularity is constantly increasing. Most franchise networks (about 85\%) are Polish, but foreign franchises are also developing successfully in the market of this country. Almost 100 new franchising networks and several thousands of licensed companies are founded every year. Foreign investors are attracted by a stable economic situation and lower, compared with other European countries, labour costs and modest business expenses.

Relations between the franchisor and franchisee are regulated by a franchise agreement, which in Poland belongs to unnamed treaties, that is, those which are not provided for in the Civil Code of the state. Therefore, a franchise agreement is concluded in accordance with the norms of the national legislation, the laws of the European Community, and the requirements of the Code of Ethics.

There is no legally binding obligation to disclose information before concluding a franchise agreement in the Civil Code, as it is imposed in the legislation of most European countries, but such an obligation could be stipulated in the provisions of the treaty itself. This is an effective means of protecting the rights of the franchisee in the case of non-disclose of the important information or providing false data by the franchisor.

Polish civil law does not also provide for essential terms and conditions of a franchise agreement, so the parties determine them at their own discretion in accordance with the recommendations provided in the Code of Ethics.

The validity of the franchise agreement is not legally determined; however, the maximum allowed duration of the contract will depend on whether it contains any provisions restricting competition.

A franchise agreement is a long-term contract, which is concluded for a limited period, or for an indefinite period. The civillaw provides for two options to terminate an agreement before its expiration: termination upon notice and rescission. It is recommended to include in the contract the provision on the conditions of franchise agreement termination.

The franchise agreement can be renewed by the mutual consent of the parties. In the case of franchisor's refusal to continue cooperation, a franchisee does not have the right to demand compensation. Theoretically, a franchisee could potentially claim unjust enrichment or breach of principles of community life, but practically it would be very difficult to prove (Franchise, 2019). 


\section{References:}

Polish Franchise Organization. Poland - country of chance. URL: http://franchise.org.pl/poland-country-ofchance2

Poland Country Commercial Guide. Poland - Franchising. URL: https://www.export.gov/article?id=PolandFranchising

Maciej Gawroński (2015). Poland. The Franchise Law Review. Edition 2. Law Business Research Ltd, London.

Franchise 2019. Poland. URL: https://iclg.com/practice-areas/franchise-laws-and-regulations/poland

Ustava z dnia 23 kwietnia 1964 r. Kodeks cywilny (Dz.U. 1964 Nr 16 poz. 93). URL: http://isap.sejm.gov.pl/ DetailsServlet?id=WDU19640160093\%20-\%D1\%81\%D0\%B0\%D0\%B9\%D1\%82

Anna Stronczek. Insights into franchising in Poland: a review of empirical and theoretical perspectives. URL: https://www.researchgate.net/publication/316879162_Insights_into_franchising_in_Poland_a_review_ of_empirical_and theoretical_perspectives

European Code of Ethics for franchising. URL: http://www.eff-franchise.com/Data/EFF\%20Code\%20of\%20 Ethics\%20for\%20Franchising\%20-\%20FINAL\%2007122016.pdf

Commission Regulation (EU) No 330/2010 of 20 April 2010 on the application of Article 101(3) of the Treaty on the Functioning of the European Union to the vertical agreements and concerted practices categories. URL: https://eur-lex.europa.eu/legal-content/EN/ALL/?uri=CELEX\%3A32010R0330 